\title{
The socio-cultural-symbolic nexus in the perpetuation of female genital cutting: a critical review of existing discourses
}

\author{
Tammary Esho (1), Steven Van Wolputte (1), Paul Enzlin (2) \\ (I) Institute for Family and Sexuality Studies, KULeuven, Belgium \\ (2) Institute for Anthropological Research in Africa, KULeuven, Belgium
}

\begin{abstract}
Female Genital Cutting (FGC), also known as Female Genital Mutilation (FGM) and Female Circumcision (FC), continues to be a prevalent practice in many parts of the world and especially in Africa. This is somewhat perplexing given the concerted efforts aimed at eradicating this practice. This article argues that the perpetuation of FGC is due to the unintended effects of marginalization experienced by individuals and groups of women as a result of the approach of some of the anti-FGC global discourses and policies put forward to eradicate the practice. This, we argue, happens when the social structure that provides such groups and individuals with a sense of identity and belonging breaks down. Therefore, the attack on what practicing communities consider to be of crucial cultural value causes a re-focus on the practice resulting in a re-formulation and re-invention of these practices in a bid to counter the feelings of alienation. FGC is thus reframed and reconstructed as a reaction against these campaigns. This article intends to investigate the socio-cultural-symbolic nexus surrounding the practice of FGC, its meaning and implications with respect to its continued existence. It draws examples mainly from communities in Kenya that practice FGM as a rite of passage into adulthood. Herein, perhaps, lies the driving force behind the practice in this contemporary age: it carries a lot of significance with respect to transformational processes, and it is seen as crucial in the representation of the body, identity and belonging. The aim of this article is not to defend FGC's continuation, but rather to explore the interplay between its changing socio-cultural dimensions as a counter-reaction to the eradication discourse and policies. In this way we will try to explore some of the factors that lay behind its perpetuation.
\end{abstract}

Key words: body practices, female genital cutting, female circumcision, femininity, cultural identity

\section{FGC, a continuously re-invented ritual}

The term Female Genital Cutting (FGC), variously referred to as Female Genital Mutilation (FGM) and Female Circumcision (FC), is a practice that involves partial or total excision of the external female genitalia for non-therapeutic purposes (WHO, 2008). This article intends to use both the terms FGC, in an attempt to maintain a neutral perspective, and FC as a term used by many practising communities. The term FC has been argued to connote a cultural relativistic perspective; it also appears misleading as it blankets all forms of genital cutting by making an analogy to male circumcision (Walley, 1997; James \& Robertson, 2002). The practice of FGC is diverse in terms of both the ways it is practiced amongst various communities and in terms of its procedure and cultural significance (James \& Robertson, 2002). 
Cultural practices and discourses in any society are re-transformed and re-invented in order to accommodate the needs of a society at any given time. They are in a dynamic state, constantly adapting to new ideologies of a globalizing modern world. Practices such as FGC are not immune to such changes. This situation is not only reflected in traditional practices themselves but also in strategies for FGC abandonment. For instance, a change can be detected in the eradication discourse approaches: FGC used to be defined as a traditional practice with serious health consequences, but then the discourse was reframed by defining it as a human rights issue (Igras et al., 2004). This change is a result of the realisation that the initial approach was counterproductive; an approach that in effect became an obstacle to realising the original aim of eliminating FGC. (These different approaches to interventions in various community-based projects in Africa have been further elaborated upon in articles by Igras et al., 2004: Abusharaf, 2006; Leye, 2008). Similarly, FGC's significance and practices change while adapting to new challenges presented by the eradication discourse, by disintegrating cultural models and by the demands of everyday life (Johansen, 2006).

Rabinow (1975), a renowned cultural anthropologist, pointed out that 'tradition is a moving image of the past ... that is opposed not to modernity but to alienation' (Rabinow, 1975, I). This feeling of alienation is experienced as a result of the process of 'othering' (Mohanty, 199I). In Mohanty's (199I) critique of western feminism she argues that the 'self' is defined by the 'other' as the periphery defines the centre. In this article we borrow from these arguments indicating that traditional practices which define society, individuals and groups, are continually being either promoted or discouraged by external peripheral pressure. This article subsequently argues that the alienation and marginalization experienced by societies as a result of what some community members perceive as an attack on their cultural value systems may cause a mirroring of traditions from the past to the present. These attacks may cause a reaction that result in the re-formulation and re-invention of traditional practices. To be more specific: when FGC practice is singled out for eradication, the society may begin to view this practice as a distinct feature of its identity. It is thus the perspectives of 'others', external to the society, that give a people the opportunity to experience their distinctness.

This article argues that efforts to abandon FGC in some instances can lead to the unintended marginalization of the FGC practicing individuals and societies (James, 2002: Mohanty, I991). This may consequently cause a renewed focus on women's bodies, leading to the re-invention and perpetuation of FGC. As a result, the unintended re-formulation and perpetuation of FGC might render the practice more resistant to abandonment campaigns among various FGC practicing societies. Simultaneously, awareness of body knowledge, capabilities and habits associated with FGC is fundamental to the comprehension of its persistence by people external to FGC practicing societies (Abusharaf, 2006). This article thus attempts to reveal the socio-cultural symbolic nexus, a complex and multifaceted process women are confronted with when making decisions to perpetuate the practice, sometimes on an individual basis but mostly coerced by a larger group of family members (Shell-Duncan and Herlund, 2000). 


\section{The (re)invention of FGC: a historical Kenyan perspective}

'Invented traditions' have been described as a "set of practices normally governed overtly or tacitly by accepted rules and of a ritual or symbolic nature, which seek to inculcate certain values and norms of behaviour by repetition, which automatically implies continuity with the past" (Hobsbawm, I983). The past in this sense does not always refer to an ancient custom - Hobsbawm ( 1983 ) describes 'invented traditions' as responses to novel situations that take the form of reference to old situations, but not necessarily from an ancient past. FGC practice has occasionally been represented as ancient and still conducted in its original forms (Ahlberg et al., 2009). Research has indicated, however, that FGC practices are constantly evolving. Indeed, socio-cultural, economic, religious and political changes influence the re-invention of traditional practices over time. For instance, individuals and societies began changing their traditions and moral value systems as a reaction to European colonization of Africa (Ahlberg et al., 2009). The following sections will focus on some of these changes.

\section{The encroachment of Christian and colonial values on FC culture in Kenya}

The socio-cultural-political-economical dimension that played a role in changing the practice of FC can be seen amongst various ethnic groups in Kenya. Amongst the Kikuyu for instance, Ahlberg and colleagues (2000) found that members resisted the ban on female circumcision instigated by some of the missionaries in Central Kenya by breaking away from mainstream missionary churches to form independent churches that allowed female circumcision. Pedersen (I991) states that in 1926, missionary pressure and a certain level of official concern about the prevalence of clitoridectomy (cliteridectomy is a term used by Pedersen (I99I). It refers to a type of FGC where the clitoris is excised) amongst the Kikuyu led the Governors of East African dependencies to meet in order to devise ways to combat the practice. Around the same time, a Kikuyu native council of elders had already passed a law requiring all operators to be licensed and to restrict the extent of cutting to what was referred to as a 'simple clitoridectomy'. The decision to ban the practice altogether and to refuse communion with Christians who did not forswear the practice, led to some Kikuyu's rebelling against the British Government. This, in its turn, resulted in the re-adoption of the more brutal form of clitoridectomy (Pedersen, I99I). The difference between minor or brutal forms of clitoridectomy may have involved the amount of tissue excised. Either way they would both fall under type I or II FGC according to the WHO classification, involving partial or total removal of the clitoris and/or the prepuce and/or labia (WHO, 2010). Thus, the practice of FGC in this case was used as a form of nationalistic and anti-colonial protest (Thomas, 2000).

Among the Kikuyu, a group of women initiated together, formed an age-group. This was a basic unit in their social organization (Pedersen, 199I). During the Colonial era, women rebelled against attempts to eliminate the practice as this threatened the process through which they became part of a society. Robertson (1996) suggests that the persistence of the practice was linked to the fact that it had organizational implications on the female age-group system, thus constituting a crucial determinant of how these women 
perceived their existence and their role in society. Others felt that Kikuyu identity was threatened by these religiously motivated campaigns against FC, campaigns that were counteracted by some encouraging FC perpetuation (Kenyatta, 1938).

\section{The encroachment of modern-day global ideologies on FGC practice in Kenya}

In Kenya the development of the practice of FGC has continued due to the encroachment of global ideologies into existing cultures. This, we argue, is due to the changing and sometimes conflicting ideologies concerning gender and sexuality that arise from certain global perspectives. Although from a Western point of view, African traditions have previously been viewed as culturally savage and primitive (Christoffersen-Deb, 2005; Ahlberg et al., 2000), more recent abandonment strategies have attempted to build on local cultural traditions while implementing approaches toward FGC elimination (Leye, 2008: Evelia et al., 2007; Diop et al., 2004). To date, an extensive network of African-based organizations, including governmental and non-governmental organizations, promote the prevention of FGC world-wide. Many of them take the local perspectives on FGC as the point of departure, trying to involve local girls and women in the development of their programmes (WHO, 2008; Rahman and Toubia, 2000).

A legal approach has also been implemented in many countries in order to ban FGC, to offer legal protection to women, to prosecute the perpetuators and to train and sensitize the communities (WHO, 2010; Leye, 2008; Evelia et al., 2007). Various successful programmes have been implemented by organizations such as the WHO, TOSTAN, Population Council, UNFPA, UNICEF, USAID and the Donor Working Group, to name but a few. Some of the programmes include the integrated social development approach which addresses various aspects of gender, social, health and economic development of a specific community. Furthermore, the positive deviance approach has also proved useful where individuals who reject FGC motivate others in the community to reject the practice. In addition, there are programmes that focus on motivating and teaching the community about the adverse health consequences of FGC, programmes that are integrated into community-based intervention approaches (Leye, 2008; Evelia et al., 2007).

Other programmes have borrowed from the positive traditional significance of the coming of age ritual by introducing aiternatives for the traditional cutting ceremonies. They try to provide girls with a coming of age ceremony through an educational programme involving sexual and reproductive health issues, where FGC is discussed, but excluded (ShellDuncan and Herlund 2006; Toubia and Sharief, 2003). In Kenya, this is known as the 'alternative rite of passage', the 'circumcision through words' or the 'ritual without cutting'. These projects are run by the organisation Maendeleo ya Wanawake Organisation (MYWO) and the Programme for Appropriate Technology in Health (PATH) in Kenya (Evelia et al., 2007).

Various community-based programmes such as the TOSTAN program in Senegal (Diop et al., 2004) and other educational programmes have been targeting grass-roots participation in creating awareness concerning FGC abandonment initiatives (Meyers, 2000). Some of these strategies have been helpful in changing attitudes about FGC in various countries. In Kenya, for instance, a gradual decrease in prevalence rate of FGC 
has been reported from $38 \%$ in 1998 to $32 \%$ in 2003 and to $27 \%$ in a more recent survey (KDHS, 2008/9). Although these approaches have not been effective in quickly eliminating FGC, they have had success in creating awareness and providing knowledge especially to women, hence enhancing autonomy over their health and sexuality (Meyers, 2000).

In the midst of these global initiatives and the increased awareness regarding FGC abandonment, women seek to find ways to re-negotiate their cultural identity and femininity in a variety of ways. This re-negotiation process is experienced differently amongst various communities and individuals. Some communities report changes in attitudes resulting in the abandonment of FGC while others may resort to clandestine procedures (Arnfred, 2005). For instance, there have been reports about the medicalization of FGC in many communities (Refaat, 2009; WHO, 2008). This trend is experienced among the Kisii ethnic group of Western Kenya. Instead of stopping the practice altogether, Kisii women maintained the practice by opting for a medicalized procedure, done in hospitals and using medical personnel and sterile equipment as it is seen as a harm-reducing strategy (Christoffersen-Deb, 2005). In some cases where women have gone through the infibulation type of FGC, (infibulation is the most extensive form of FGM, sometimes involving the excision of the clitoris) there has been an increased demand for re-infibulations (Serour, 2010). As a result of the increasing trend towards medicalization and re-infibulations, a response from the global society to tackle the situation has been put forward. There is now a global FGC eradication strategy that stimulates health care professionals to take a stand in favour of abandonment and to refrain from performing FGC, including re-infibulation (WHO, 2010: Serour, 2010). A situational analysis done in Kenya reported a trend towards reducing the amount of tissue cut amongst some communities. This change can be attributed to an increased awareness of the ongoing eradication campaigns and the global policies and discourses associated with it (Evelia et al., 2007).

For some practising communities, the importance of having witnesses to the procedure is a key aspect of the practice, as well as having open celebrations to mark the occasion. This ceremonial aspect of the practice, however, is declining in many communities. The reasons behind this decline may range from its being a costly affair that some parents cannot afford, to its being time consuming diverting the girls' attention from school, to the existence of legislation that prohibits the practice (UNICEF, 2005). For example in Kenya, the banning of the practice through the Children's Act (Evelia et al., 2007) has had major implications in reducing the public celebrations as perpetuators try to avoid being noticed and subsequently prosecuted.

Such reported changes take place as a result of the dynamic processes of internal socio-cultural models and their interplay with external global discourses and policies. These complex factors play a significant role regarding the continuous re-framing and re-invention of traditional practices such as FGC. Re-framing of the practice takes place as the meaning and context associated with the practice change. This re-framing consequently leads to a re-invention of the practice. The re-invention of this tradition is a response to novel situations, in this case a reaction to the ever-changing global discourse. In the following section, this article does not seek to justify the reasons for FGC's per- 
petuation but rather to contribute to the ongoing discourse by providing a theoretical lens suggesting the reasons that contribute to FGC's perpetuation. This will mainly be achieved by taking into consideration the feminist and anthropological epistemologies regarding bodily practices.

\section{The body as a focal point in the re-invention of FGC}

Throughout history, individuals continue to find ways to re-invent and re-define themselves, using their bodies as the medium to achieve this. The shifting ideals of beauty and/or femininity are continually being experienced at an individual and/or a societal level - and the body becomes a focal point for the expression of such changes in the perception of beauty. In the context of society becoming more individualistic, people increasingly opt for different and sometimes unique means of self-expression. The capacity for self-modification and adornment has been and continues to be an essential feature of humanity (Reischer \& Koo, 2004).

It is clear that the body is often used as a canvas on which social, cultural and political changes are projected, and at the same time, the body is a major focus and objective of these changes (Van Wolputte, 2004). Bodily modifications and practices continue for various reasons today, ( cosmetic surgery, tattooing etc) as they have over previous centuries with practices such as foot-binding, skin-whitening, the wearing of corsets or high-heels and so on (Frank, 2006). In fact, the ideals of beauty and femininity are projecting the body as a site for the construction and performance of gender (Reischer \& Koo, 2004).

In the context of Africa, colonial and post-colonial development interventions contributed to the economic, political and cultural disenfranchisement of women (Hodgson, 2001). Hence, the response to marginalization and impoverishment, colonialism, and violence caused the fragmentation of bodies in terms of identity and belonging. The perpetuation of cultural practices and especially FC may thus be a counter reaction to the bodily fragmentation for women experiencing a loss of identity and belonging.

Societies have and continue to be confronted with changes in modern-day sociocultural political systems (Hodgson, 200I). From a Western perspective, African women have especially been represented as downtrodden, subjugated, victims of colonialism and male dominance (Cornwall, 2005). Subsequently, Western civilization was imposed by the colonialists who were oblivious to the fact that the African traditional communities had historical patterns of marriage, kinship, exchange and power that structured their societies (Hodgson, 2001). Western civilization thus legitimized its interventions by referring to women as subjugated, hence initiating what they regarded as the liberation of women with a concern to improve the African woman's well-being (Cornwall, 2005). As with other traditional practices, FC was judged to be a violation of the notions of Christianity and as contrary to notions of civilisation and modernity (Njambi, 2004). Traditional religions and customs were thus viewed as being in contestation with Christianity.

As a result of the dismantling of their traditions, some women as well as men renounced aspects of traditionally defined identity and gender roles. The changing of traditions occurred for various reasons, such as through formal education. Boys and girls 
were compelled to leave their rural homes to go to the mission schools set up by the government and missionaries where they were instructed through formal education and they received religious instructions from Christian missionaries (Kanogo, 2005). This led to processes of social differentiation and fragmentation of the individual's sense of identity and belonging (Kanogo, 2005). The boys and girls, who became men and women, were viewed by others in their communities as lost sheep, not having undergone the traditional ways of legitimating cultural identity and belonging.

It is clear that the changes globalization brings, substantially affect the principles of cultural identity formation and belonging. New opportunities such as education and career training provided women with the opportunity to resist what they began to view as traditional forms of social control - many of them could now leave their villages and stay in the towns to work in order to earn a living. At the same time, the culture of individualization that promised emancipation introduced different forms of control to women's work and even to their sexuality (Arnfred, 2005). Many women became reluctant urbanites, pushed into trading and other careers outside their rural homes by circumstances beyond their control (Robertson, 1996). As a result, by moving out of their comfortable cultural spaces, women began to lose their identity, thus a sense of despair and isolation set in (Hodgson, 2001). By re-focusing on the body, women searched for new ways to redefine themselves. An example of this re-focus on the female body is seen among the Jola community in Senegal, where as a response to globalization, a re-introduction of FGC practice has been experienced (Dellenborg, 2004). In fact, the wider socio-cultural context surrounding this practice provided individual women with self-esteem, cultural recognition and space for agency (Esho et al., 2010; Dellenborg, 2004). It is here perhaps in the attempt to fight against feelings of alienation and disempowerment that we find the motivation for the continuous re-invention and re-formation of body practices. In the following sections, we investigate some of the socio-cultural-symbolic nexus that play a significant role in the perpetuation of FGC in various cultural contexts.

\section{The socio cultural symbolic nexus associated with FGC}

In order to understand why the practice is perpetuated it is important to unravel the socio-cultural-symbolic nexus (a term used by Esho et al., 2010) associated with FGC. The meanings of this nexus are not fixed, but depend on the interpretations of bodily practices in different cultural contexts. In many contexts, the reasons vary as to why FGC is carried out, as does the age of those on whom it is conducted. This section gives examples from various FGC practicing communities to show the difference in meanings and symbolism associated with it.

Amongst the Maasai for instance, FC is considered an important rite of passage from childhood into adulthood (Esho et al., 2010). Therefore, the practice is viewed as a central entity in the definition of female identity and belonging, and also in the legitimation of womanhood, sexuality and fertility (Esho et al., 2010; Arnfred, 2005; Talle, 1988). Importantly, the practice often provides an assurance for marriage and motherhood (Lightfoot-Klein, 1989). 
In other communities, FGC is not viewed as a rite of passage into adulthood. This is the case in societies where FGC is performed on babies, young children or teenagers. For instance, among the Omdurman community in Sudan, circumcision can take place anytime between birth and puberty not just as a Muslim tradition but also as a means of preserving a girl's virginity (Cloudsley, 1983). Also among the Somali, FGC is done to ensure a successful transformation of young girls aged five to eight to women by ensuring the preservation of their virginity before marriage (Johansen, 2006; Jaldesa et al., 2005). Thus the meanings regarding the practice vary in different communities. This means that understanding the value systems of a particular culture may play a significant role in understanding FGC's perpetuation in various contexts (Knudsen I994).

Pain is an aspect of the FGC procedure that is experienced as part of the socio-cultural-symbolic nexus. The symbolism associated with the pain of undergoing this genital procedure has been described as culturally induced "ritual pain" (Johansen, 2002; p. 319). Ritual pain is perceived differently among various communities. In her study amongst Norwegian Somalis, Johansen (2002) states that pain is seen as part and parcel of womanhood. It is intrinsic to the tradition, in the sense that it both plays a social function and is experienced individually. Pain is reactivated during various stages of a woman's life such as sexual debut and child birth (Johansen, 2002). However, Johansen indicates that for most of these women, pain was experienced on an individual level with a sense of helplessness and loss. Thus, although embedded in cultural traditions, the pain has been described in some instances as so overwhelming that it begins to threaten the very bases on which it is founded. This awareness can be the starting point for women who begin to question basic cultural values - often enhanced by the fact that they live outside of their cultural contexts and thus experience different values and expressions of female identity (Johansen, 2002).

In contrast to Johansen, Walley (1997) suggests that pain as an intrinsic part of the ritual is socially meaningful and in some communities it is something to be endured as fostering a positive transformation of the self. Amongst the Maasai for instance, genital cutting serves as a permanent sign of the initiate's change of status and the ability to endure pain, as suggested in the general analysis by Schlegel and Barry (1979) and La Fontaine, (1985). Thus, initiates experience - through their skin - pain, death and rebirth, after which their relationship with other initiates, age-set members and the community at large is re-defined (Esho et al., 2010; Schildkrout 2004).

The symbolic entry into adulthood for a community such as the Maasai provides a sense of triumph to the initiate through a physical and psychological test (Robertson, 1996).

FGC: A mark inscribed on the body

Merleau-Ponty (1962) suggests that bodily actions are not to be understood as expressing or objectifying meanings originating in the mind but rather that the meaning is in the action itself. This article argues that the socio-cultural-symbolic nexus involved in processes of bodily inscription provides a motive for FGC and its perpetuation. The body plays an active role in the formation of identity and gender (Christoffersen-Deb, 2005). 
In the ritual of FC the body becomes a site for the inscription upon which the relationship between the individual and society is constructed (Schildkrout, 2004). The creation of social meaning takes place continuously by responding to challenges experienced in life. Njambi (2004) suggests that bodies do not exist in a vacuum but rather that they are made and negotiated through everyday rituals and performances. Thus the body is a product of the times and places in which it exists (Walley, 1997).

There are different ways and contexts through which bodies are modified. It has been argued that body modification is an important aspect of a culture because gender and social identity are shaped and communicated through the body (Dellenborg, 2004; Turner, 1980). The body is thus constituted through cultural practices (Bordo, 1993). For instance, the perception of beauty varies depending on where an individual resides (Reischer \& Koo, 2004). In Western countries for instance, the condition of thinness is widely accepted as aesthetically preferable to largeness, which is more preferred in Saharan and Sub-Saharan countries (Popenoe, 2004). Such a difference could however be attributed to the different economic conditions where rich countries with plenty of food prefer thinness, while poor countries where food is scarce may prefer being fat as a sign of good health. This article suggests that body symbolism related to cultural practices, be it FGC, cosmetic surgery, tattooing, and so on, should be seen from a different perspective depending on the context surrounding a subject. The meanings of body practices are therefore constantly negotiated and re-negotiated by various social actors - men and women alike (Dellenborg, 2004). Thus the body not only reflects these practices, but also has the capacity to challenge them. It participates in the creation of social meaning (Reischer \& Koo, 2004). It has also been claimed that the body can be seen as a 'natural symbol' with which to think about nature, society and culture (Douglas, I978). The body is a symbol for society, a signifier of the social world it inhabits, an instrument of lived experiences, and a surface of inscription (Joyce, 2005; Reischer \& Koo, 2004).

As a result, the body is not solely viewed as a biological entity but as influenced by socio-cultural and historical phenomena (Reischer and Koo, 2004). In this sense, it self-mediates its relationship with the society both as a 'symbolic' and 'agentic' body (Reischer \& Koo, 2004). Firstly, the symbolic nature of the body reflects social meanings metaphorically through bodily symbols. Secondly, as an 'agentic' body, the body highlights its role as an active participant or agent in the social world, a site for construction and performance of gender consequently signifying a social change (Reischer \& Koo, 2004). From this point of view, FC could be understood as a kind of "physical and symbolic manipulation of the body in relation to the world and of the world in relation to the body" (Moore, i999, pi3).

In FGC practising communities, women play a central role in fostering its perpetuation whether or not there is consent or cultural cognisance from the perspective of the young girls who have to undergo this practice. These women may not necessarily view FGC as a practice done to them but for them - as a bodily inscription that helps them to physically and mentally embody the social meanings and significance of the practice (Esho et al., 2010). The aspects of social acceptance and social convention thus play a 
significant role (UNICEF, 2005). Research has shown that for women and girls the pressure to conform to traditions plays a significant role in the decisions to undergo FGC. The women thus become active agents as they play a role in shaping their social reality (Dellenborg, 2004). Subsequently, not only their self-esteem as beautiful and respectable women is improved, but also the relationship between the women and their families/ societies is enhanced. In fact, a woman's status improves in relation with the society, after making the complete physical and psychological transformation through this bodily inscription.

\subsection{FGC: A social inscription}

Throughout history, bodies have continuously been modified for social reasons. As we have seen in the above section, social convention and social acceptance play an important role in the decisions to perpetuate FGC. The body is regarded as a material object, a living and acting organism that gains social identity through its appropriation as a social and cultural subject (Turner, 1995). The body is in fact required to conform to societal expectations. In referring to FGC as a social inscription, this article accords with Johnsdotter and Essen (2010) who suggest that genital modifications are never purely about anatomy and physiology but are entangled in a broader web of cultural norms and ideologies. The body is both a product and a producer of processes of appropriation in its environment (Turner, I995). Full membership into the adult social world is one of the social benefits an individual gains by going through FGC (Ahmadu, 2000). Subsequently, to live in a social world implies to continually adapt to and be subjected to conceptual orders and social discourses (Moore, 1999).

The body is a physical entity, a representation and a medium of expression that is controlled and restricted by a social system (Douglas, 1978). The physical skin becomes a social skin inscribed by signs and meanings that represent the socialized self by mediating its relations to the social world (Turner, 1980 ). The body becomes not only the site where culture is inscribed but also the means by which the individual is inserted into the cultural landscape (Schildkrout, 2004). In FGC ritual practices, therefore, individuals may not act for themselves but for the social group (McGarrahan, 199r). For instance, due to the attack on this practice by Christian missionaries and colonialists, a need for social cohesion was experienced by the Kikuyu of Kenya. To circumcised women for example it was evident that they belonged to this society because FGC provided a sense of unity and power. Kenyatta, an anthropologist who later became Kenya's first president when Kenya gained independence, claimed that keeping traditions such as FC in place played a crucial role in uniting the society (Kenyatta, 1938). Hence, the chance to fully participate in traditional customs and rituals involves a broader, deeper and essential dimension of strengthening the identity of those involved as members of a community (Karim, 1998).

Social identity and sexual scripts associated with FC are constantly being negotiated by people living in practicing communities. Silverman (2004) suggests that FGC as a rite of passage is a symbolic message concerning personhood, gender, cosmology, status, and community that is literally inscribed in the body. Several studies have indicated the 
symbolic importance of a ritual such as FGC that is explained to young girls during their childhood as a necessary procedure (Talle, I988; Gruenbaum, 200I). The interactions between society and the body may be expressed in many ways. In social symbolism for instance, society is inscribed on the expectant canvas of human flesh or body (ScheperHughes \& Lock, 1987). This indicates the need of an individual to comply with the societal demands. The body therefore becomes socially inscribed when it is no longer defined on the basis of its intrinsic features but rather on the basis of the extrinsic. The extrinsic mainly involves the social construction of meaning and interpretations as suggested by Van Wolputte (2004) in his study of the Himba in Namibia.

In the following section we delve into the epistemological background of FGC perpetuators as active social actors and agents in shaping their social reality.

\subsection{Women as active agents in the re-invention and perpetuation of $F G C$}

The Western world has viewed female agency as impossibility in the context of patriarchy and male dominance (Frank, 2006). Subsequently, this has influenced the way in which a practice such as FGC is viewed by an outsider's eye since female agency and autonomy seem inconceivable in the context of patriarchal societies. This conventional feminist epistemology has come under attack from various fronts, most frequently from feminists themselves (Davis, 2003; Frank, 2006; Mahmood, 2005). As the socio-cultural symbolic nexus indicates, FGM can be seen as both a social and a bodily practice, and in both cases it is historically and culturally produced. Within the feminist epistemology there has been a backlash against a-historical and culturally empirialistic concepts that focus on the interpretation of humans, rather than on productions of and responses to systems of power and domination (Frank, 2006).

As a result of this backlash, feminist epistemology has recognized the agency and autonomy of women who individually choose to undergo body practices, for example in genital cosmetic surgery. Ahmadu (2000) argues that women's power and influence among the Kono women of Sierra Leon is a major factor in the perpetuation of FGC. In patriarchal societies it seems that women are often active agents in producing and reproducing their social realities and social structures. The body then plays an important role by actively participating in the processes by which social meanings are given definition (Merleau-Ponty, 1962). It has been argued that individuals sometimes internalize cultural norms within certain cultural confines and consequently embody these norms through their lived experiences (Frank, 2006). Thus women may choose voluntarily or be coerced into accepting FGC as a result of the ongoing cultural discourses surrounding them.

It has been suggested that to consider and understand the way these norms are lived will provide a better understanding of female agency in relation to cultural practices (Mahmood, 2005). One of the examples indicating a process of female agency is the experience of Njambi (2004), a feminist sociologist who comes from the Kikuyu ethnic group in Kenya. While narrating about her circumcision experience, she emphasizes that although her parents were ardent Catholics and hence rejected the practice on the basis of their Christian beliefs, she made her own decision to have it done against her parents' 
wishes. She adds that from a historical basis the practice was significant to her as it involved the instillation of female empowerment. This tells us that the Kikuyu viewed FC in a positive light, rather than it being a site for women's oppression and domination. This was especially acknowledged during the anti-colonial struggle in Kenya, where the discourse of FGC promoted an ethic of boldness and courage, a platform where women could engage in militant anti-colonial struggle together with men (Njambi, 2007).

In present day Kenya, the significance of female circumcision has changed and the practice is regarded differently by different individuals as well as by different groups of women. As Njambi above states, it was while growing up that the idea of the need for circumcision was instilled in her and thus she went through the practice because of what it meant for her as an individual woman. This was regardless of how others - such as her parents - perceived it; for her it was about a personal journey. This is just one example of the situation in which the practice tends to have a personal rather than group significance: Njambi (2007) even presents the practice as a means of empowerment. FC provided access to social, political and economic power in an undeniably patriarchal society (Njambi, 2004). Hence, the perpetuation of FC served both the interests of the individual and those of the community. It reinforced the sense of female solidarity that was experienced during and after these ceremonies, consequently leading to the re-formation or re-invention of traditional practices.

While the Maasai have a patriarchal structure (Galaty, 1979: Llewellyn-Davies, I98I), women do play an important role in social production. This also includes the production of masculinity through taking part in various ritual and religious ceremonies involved in transitory moments (Hodgson, 2000: Talle, 1988). In addition, it is through women that the transition of boys into men is made possible, through the constant change in configuration of men's relationship with women and of men with each other (Spencer, 1988). Women as mothers and wives support elderly men in the process of age-set rituals, which mark the life stage transitions of boys to men and then to elders (Hodgson, 2000). Mothers occupy a central role in determining whether boys have reached the age to undergo initiation and also in deciding when and whom their boys will marry eventually. It is on the basis of these decisions that young men might be allowed to become community leaders. Clearly, for Maasai women, FGC grants them an opportunity to acquire a status that enables them to influence society in both private and public domains.

Another example of a patriarchal social structure that appears to empower women is that of the Turkana in the North-Western province of Kenya. In that society it is through rituals that women are positioned favourably in terms of property and power relations, both socially and structurally (Broch-Due, 1999). These rituals also are crucial in the construction of their social system (Galaty, 1979; Llewellyn-Davies, 1981).

These examples emphasize the importance of the role of women in a society that is traditionally male dominated. It is ironic that in those societies the power men acquire can only be achieved through the relationships with their mothers, wives, or other women in the community. Such a patriarchal structure thus appears to serve the interests of everyone in society. Hence, it is through these kinds of social structures, where both men 
and women participate in the formation of identity, gender and norms of sexuality, that the continuation and maintenance of culture is ensured.

Bodily modifications are employed to reflect and motivate processes of social reform (Reischer \& Koo, 2004). Reischer and Koo continue to assert that women's bodies and social constructions of the ideal female body do more than reflect a woman's position in society; they also offer a means for negotiating, redefining and reconceptualising that position. Female subjectivity and agency in the transformation of identity is therefore imperative, not only in the reproductive capacity but also in the negotiation of gender and power relations in society. This aspect of the body - by which women can achieve agency - has been mentioned as a third element of the body politic, after descriptions of the natural body and social body (Scheper-Hughes \& Lock 2004). This has been defined as the way in which the body embodies power and control. In the example of FGC, making this transformation enables women to embody the consequences of social meanings and the significance of this cultural practice by self-empowerment and by defining and defending their position in society. This shows that women are actively engaged in reconfiguring their own identities (Hunt, I997; Hodgson \& McCurdy, 2001).

Subsequently, this article concurs that cultural practices should not always be seen as a site for domination and conformity, but sometimes also as a site of multiple possibilities, where individuals and societies become actively involved in inventing and reinventing traditional practices (Njambi, 2007). The social and cultural organisation of a society, including gender organization and ritual processes, are produced, maintained and transformed through the socio-cultural power relations between and among men and women in any given society (Connell, r987; Di Leonardo, I991: Hodgson, 2001; Spencer, i988).

Although social coercion and pressure to conform to traditions also play an important role, they are not enough to explain FGC's perpetuation (Ahmadu, 2000). The above argument demonstrates that women's agency should not be left out in attempts to understand FGC's perpetuation. The meanings and interpretations of FGC remain a powerful driving force among these women, despite rapid changes in global society. Thus, modernity and tradition coexist and intermingle, as evidenced by the experiences of some individuals and societies that continue to perpetuate FGC (Ahmadu, 200o). It is therefore crucial to further encourage the incorporation of strategies that recognize women's active role and agency in the re-invention and perpetuation of FGC when developing strategies to enhance the abandonment of FGC.

\section{Conclusions}

The re-imagination and re-invention of FGC is a general indication of changes taking place regarding both the symbolic and the cultural significance of the practice. It is a means to interlink effects of globalization and those of living traditions by continuously negotiating and altering some aspects of why, how, and when the procedure is done. The globalizing society thus creates a platform for the re-formulation and re-invention of body practices. Women in FGC practicing societies respond by re-formulating and reinventing its meanings and interpretations. 
This article suggests that FGC intervention strategies should ensure that as a result of their programmes women do not become more marginalized and disempowered. The strategies should focus on being socially grounded, by understanding the women's sociocultural context. It is also crucial to encourage both insiders and outsiders at the forefront of the anti-FGC campaigns to be more aware of the changing dynamics of culture and its interplay with global ideologies, which - thanks to the abandonment campaign - these FGC practicing communities are becoming more and more aware of.

\section{References}

Abusharaf, R. (2006). Introduction: The Custom in Question. In R. M. Abusharaf, (ed.) 2006. Female Circumcision: Multicultural Perspectives. University of Pennsylvania press.

Ahlberg, M. B., Njau, W., Kiiru, K., \& Krantz, I. (2000). Gender Masked or Self-inflicted Pain: Female Circumcision, Eradication and Persistence in Central Kenya. African Sociological Review; 4, 35-54.

Alberg, B.M, Kamau, A., Maina, F., Kulane, F. (2009). Multiple Discourses On Sexuality Implications For Translating Sexual Wellness Concept Into Action Strategies. In A Kenyan Context. African Sociological Review I3 (I): $105-123$.

Ahmadu, F. (2000). Rites and wrongs: An Insiders/Outsider Reflects on Power and Excision. In Shell-Duncan, B. and Herlund, Y. (eds), Female "Circumcision" in Africa: Culture, controversy and change. Lynne Reinner Publishers. Inc.

Almroth, L., Elmusharaf, S., El, HN., Obeid, A., El Sheikh, M.A, Elfadil SM., Bergstrom S. (2005). Primary Infertility After Genital Mutilation In Girlhood. In Sudan: A Case Control Study. Lancet 366: 385-91.

Arnfred, S. (2005). Introduction; Under Western Eyes. In (Ed.) Arnfred Signe Rethinking Sexualities in Africa (second edition). Nordic Africa Institute.

Boddy, J. (199I) Body Politics: Continuing the Anti-Circumcision Crusade. Medical Anthropology Quarterly, New Series, 5, 15-17.

Bordo, S. (1993). The Unbearable Weight: Feminism, Western Culture and the Body. University of California Press.

Braun, V. (2005). "In Search of (Better) Sexual Pleasure: Female Genital "Cosmetic" Surgery', Sexualities, 8(4): 407-24.

Broch-Due, V. (1999). Creation and the Multiple Female Body: Turkana Perspectives on Gender Cosmos. In Moore, H., Sanders, T. \& Kaare, B. (Eds). Introduction, Those Who Play With Fire: Gender, Fertility \& Transformation in East \& Southern Africa. The Athlon Press: London and New Brunswick, N.J., pp. 3-37.

Christoffersen-Deb, A. (2005). "Taming Tradition": Medicalized Female Genital Practices In Western Kenya. Medical Anthropology Quarterly 19: 408-412.

Cloudsley, A. (1983). Women of Omdurman: Life, love and the cult of virginity. Ethnographica: London.

Connell, R. W. (1987). Gender and Power: Society, the Person and Sexual Politics. Stanford: Stanford University Press.

Cornwall, A. (2005). Introduction, Readings in Gender in Africa. Indiana University Press.

Davis, K., (2003). Dubious Equalities \& Embodied Differences: Cultural Studies on Cosmetic Surgery. Lanham: Rowman \& Littlefield Publishers, Inc.

Dellenborg, L., (2004). A reflection on the cultural meanings of female circumcision: Experiences from fieldwork in Casamance, Southern Senegal. In (Ed.) Arnfred Signe Rethinking Sexualities in Africa (second edition). Nordic Africa Institute.

Diop, N.J., Faye, M.M., Moreau, A., Cabral, J., Benga, H., Cisse, F., Mane, B., Baumgarten, I., Melching, M., (2004). The TOSTAN Program Evaluation of A Community Based Education Program in Senegal. Population Council/GTZ/TOSTAN.

Di Leonardo, M. (1991). Gender at the Crossroads of Knowledge. Berkeley; University of California Press. 
The Donors Working Group on Female Genital Mutilation/Cutting). Platform for action towards the abandonment of female genital mutilation/cutting (FGM/C). New York, UNICEF, 2008. http://www.unifem.org/attachments/products/Platform_for_Action_FGMC_English.pdf.

Douglas, M. (1978). Natural Symbols. New York: Praeger.

Esho, T., Enzlin, P., Van Wolputte, S., Temmerman, M., (2010). Female Genital Cutting and Sexual Functioning. In Search of an Alternate Theoretical Model. African Identities 8 (3); 221-234.

Evelia, H., Sheikh, M., Njue, C., Askew, I. (2007). Contributing Towards Efforts To Abandon Female Genital Mutilation/Cutting In Kenya: A Situational Analysis. UNFPA/Population Council.

Frank, K. (2006). Agency. Anthropological Theory 6: 28I.

Galaty, J. (1979). Pollution and Pastoral Antipraxis: the Issue of Maasai Inequality. American Ethnologist 6: $803-8 \mathrm{r} 6$.

Gruenbaum, E. (200I). The Female Circumcision Controversy: an Anthropological Perspective. University of Pennsylvania Press.

Hobsbawm, E. (1983). Introduction: Inventing Traditions. In Hobsbawm, E. and Ranger, T. (eds), The Invention Of Traditions. Cambridge University Press.

Hodgson, D. (2000). Rethinking Pastoralism in Africa: Gender, Culture and Myth of the Patriarchal Pastoralist. James Currey, Oxford.

Hodgson, D. (200I). Once Intrepid Warriors: Gender, Ethnicity, and the Politics of Maasai Development. Indiana University Press.

Hodgson, D. and McCurdy, S. (200r). 'Wicked' Women and the Reconfiguration of Gender in Africa. Oxford: James Currey.

Hunt, N. R. (1997). Placing African Women's History and Locating Gender. Social history 14: 359-79.

Igras S., Muteshi, J., Woldemariam, A., Ali, S., (2004). Intergating Rights-Based Approaches Into Community Based Health Projects: Experience From The Prevention Of Female Genital Cutting Project In East Africa. Health and Human rights $7(2): 25 \mathrm{I}-27 \mathrm{I}$.

Jacobson-Widding, A. (1999). Chaos and Creativity: The Transformative Symbolism of Fused Categories. In Moore, H., Sanders, T. \& Kaare, B. (eds). Introduction, Those who play with Fire: Gender, Fertility \& Transformation in East \& Southern Africa. The Athlon Press: London and New Brunswick, N.J., pp. 3-37.

Jaldesa, G.W., Askew, I., Njue, C., Wanjiru, M. (2005). Female Genital Cutting among the Somali of Kenya and Management of Its Complications. Population Council/FRONTIERS/USAID.

James, S.M. (1992). Shades of Othering: Reflections on Female Circumcision/Genital Mutilation. Signs 23 (4): 103I1048.

James, S. M. and Robertson, C., (2002). Genital Cutting and Transnational Sisterhood: Disputing U.S. Polemics. University of Illinois Press.

Johnsdotter, S. and Essen, B. (2010). Genitals and ethnicity: The politics of genital modifications. Reproductive Health Matters, I8(35): 29-37.

Joyce, A. R. (2005). Archeology of The Body. Annual Review of Anthropology 34: 139-58.

Kanogo, T. (2005). African Woman-Hood in Colonial Kenya, 1900-1950. Oxford, James Currey; Athens, Ohio University Press; Nairobi, East African Educational Publishers.

Karim, M. (1998). Female Genital Mutilation; Historical, Social, Religious, Sexual and Legal Aspects. Cairo: National Population Council.

KDHS. (2008/9). Kenya Demographic Health Survey. Accessed on 24th March 201 at:

http://www.measuredhs.com/pubs/pdf/FR229/FR229.pdf.

Kenyatta, J. (1938). Facing Mount Kenya. Nairobi: Heinemann Educational Books.

Knudsen, O. (1994). The Falling Dawadawa Tree: Female Circumcision. In Developing Ghana. Smyrna Press.

La Fontaine, J. S. (1985). Inititation: Ritual Drama and Secret Knowledge across the World. Harmondsworth: Penguin Books. 
Leye, E. (2008). Female Genital Mutilation: A Study of Health Services and Legislation in Some Countries of the European Union. Thesis (PhD), Ghent University, Belgium.

Lightfoot-Klein, H. (1989). The Sexual Experience And Marital Adjustment Of Genitally Circumcised And Infibulated Females. In The Sudan. Journal of Sex Research 26: 375-392.

Llewelyn-Davies, M. (198I). Women, Warriors and Patriarchs'. In Ortner, S. and Whitehead, H., (eds), Sexual meanings. Cambridge University Press, 330-58.

Mahmood, S. (2005). Politics of Piety: The Islamic Revival and the Feminist Subject. Princeton, NJ: Princeton University Press.

McGarrahan, P. (199I). The Violence In Female Circumcision. Medical Anthropology Quarterly, 5, Contemporary Issues of Anthropology in International Health, 269-270.

Merleau-Ponty, M. (1962). The Phenomenology Of Perception. London: Routledge \& Kegan Paul.

Meyers, D.T. (2000). Feminism and Women's Autonomy: The Challenge of Female Genital Cutting. Metaphilosophy, 22:3, 469-491.

Mohanty, C.T., (1991). Under Western Eyes: Feminist Scholarship and Colonial Discourse. In (eds) Mohanty, T.C., Russo, A., and Torres, L., Third World Women and Politics of Feminism. Indiana University Press.

Moore, H. (1999). Gender, Symbolism and Praxis: Theoretical Approaches. In Moore, H., Sanders, T. \& Kaare, B. (eds). Introduction, Those Who Play With Fire: Gender, Fertility \& Transformation in East \& Southern Africa. The Athlon Press: London and New Brunswick, N.J., pp. 3-37.

Njambi, N.W, (2004). Dualisms and Female Bodies in Representation of African Female Circumcision. A Feminist Critique. Feminist Theory 5 (3): 28I-303.

Njambi, N.W. (2007). Irua Ria Atumia and Anti-Colonial Struggles Among the Gi ${ }^{\circ} u^{\sim}$ yu ${ }^{\sim}$ of Kenya: A Counter Narrative on "Female Genital Mutulation". Critical Sociology 33: 689-708.

Obiora, L. A., (2006). Afterword: Safe Harbour and Homage. In Abusharaf, R. M. (ed. 2006). Female Circumcision: Multicultural perspectives. University of Pennsylvania press.

Pedersen, S. (1991). National Bodies, Unspeakable Acts: The Sexual Politics of Colonial Policy-making. Journal of Modern History 63: 647-8o.

Popenoe, R. (2004) Feeding Desire: Fatness, Beauty and Sexuality among Saharan People. London: Routledge.

Rabinow, P. (1975). Symbolic Domination: Cultural Form and Historical Change in Morocco. University Of Chicago Press.

Rahman, A. and Toubia, N. (2000). Female Genital Mutilation: A Guide to Laws and Policies Worldwide. London, ZED Press.

Refaat, A. (2009). Medicalization of female genital cutting in Egypt. Eastern Mediterranean Health Journal, I5(6): 1379 .

Reischer, E. \& Koo, S. K. (2004). The Body Beautiful: Symbolism And Agency In The Social World. Annual Review of Anthropology 33: 297-317.

Robertson, C. (1996). Grass-Roots in Kenya: Women, Genital Mutilation, and Collective Action, 1920-1990. Signs 21: 615-642.

Scheper-Hughes, N. \& Lock, M. (1987). The Mindful Body: A Prolegomenon To Future Work In Medical Anthropology. Medical Anthropology Quarterly I, 6-4r.

Schildkrout, E. (2004). Inscribing the Body. Annual Review of Anthropology 33: 319-344.

Schlegel, A. and Barry, H. III. (1979). Adolescent Initiation Ceremonies: A Cross-Cultural Code. Ethnology I8: 199-210.

Serour, G. (2010). The Issue of Re-Infibulation. International Journal of Gynaecology and Obstetrics $\operatorname{Iog}(2)$ : 93-6.

Shell-Duncan, B. and Herlund, Y. (2000). Female "Circumcision in Africa: Dimensions of The Practice And Debate. In Shell-Duncan, B. and Herlund, Y. (eds), Female Circumcision in Africa: Culture, Controversy and Change. Lynne Reinner Publishers. Inc. 
(2006). Are There "Stages Of Change in the Practice Of Female Genital Cutting?: Qualitative Research Findings From Senegal and The Gambia. Africa Journal of Reproductive Health, 10 (2), 57-77.

Shweder, R. A. (2000). What about "Female Genital Mutilation"? And Why Understanding Culture Matters In The First Place. Daedalus, 129: 209.

Spencer, P. (1988). The Maasai Of Matapato: A Study Of Rituals Of Rebellion. Indiana University Press.

Talle, A. (1988). Women at A Loss: Changes In Maasai Pastoralism And Their Effects On Gender Relations. Stockholms Studies in Social Cultural Anthropology.

Thomas, L. (2000). Ngaitana (I Will Circumcise Myself): Lessons from Colonial Campaign to Ban Excision in Meru, Kenya. In Shell-Duncan, B. and Herlund, Y. (eds.), Female "Circumcision" In: Africa. Culture, Controversy and Change. Boulder: Lynne Rinner Publishers, pp 129-150.

Turner, T. (Ig8o). The Social Skin. In Not Work Alone; A Cross-Cultural View Of Activities Superfluous To Survival, by Jeremy, C. \& Roger, L. (eds). Temple Smith: London.

Turner, T. (1995). 'Social Body and Embodied Subject: The Production of Bodies, Actors and Society among the Kayapo'. Cultural Anthropology 10: 143-70.

Turner, V. (1967). Forest Of Symbols: Aspects of Ndembu Ritual. Ithaca, NY: Cornell University Press.

Turner, V. (1995). The Ritual Process: Structure And Anti-Structure. Ithaca: Cornell University Press.

Toubia, N.F. and Sharief, E.H. (2003). Female Genital Mutilation: Have We Made Progress? International Journal of Gynaecology and Obstetrics, 82, 25I-16r.

UNICEF. (2005). Changing harmful social convention: Female genital mutilation/cutting. UNICEF

Van Gennep, A. (1960). The Rites of Passage. London: Routledge and Kegan Paul.

Van Wolputte, S. (2004). Hang On To Yourself: Of Bodies, Embodiment, and Selves. Annual Review of Anthropology 33: 25I-269.

Walley, C.J. (1997). Searching for "Voices": Feminism, Anthropology, and the Global Debate over Female Genital Operations. Cultural Anthropology 12(3): 405-438

World Health Organization. (2008). Female Genital Mutilation. Fact Sheet Number 241. www.who.int/mediacentre/ factsheets/fs24I/en/ (Last accessed: February 10, 2009).

World Health Organization. (2010). Global strategy to stop health-care providers from performing female genital mutilation: UNFPA, UNHCR, UNICEF, UNIFEM, WHO, FIGO, ICN, MWIA, WCPA, WMA. Accessed on 13/or/201 in http://whqlibdoc.who.int/hq/2010/WHO_RHR_10.9_eng.pdf. 